\title{
Integrated AHP, profile matching, and TOPSIS for selecting type of goats based on environmental and financial criteria
}

\author{
Clara Hetty Primasari a,1,*, Retantyo Wardoyo ${ }^{b, 2}$, Anny Kartika Sari b,3 \\ a Information System Department, Universitas Atma Jaya Yogyakarta, Yogyakarta, 55281, Indonesia \\ ${ }^{\mathrm{b}}$ Computer Science and Electronic Department, Universitas Gadjah Mada, Yogyakarta, Indonesia \\ ${ }^{1}$ clara_hetty@mail.uajy.ac.id; ${ }^{2}$ rw@ugm.ac.id; ${ }^{3}$ a_kartikasari@ugm.ac.id \\ * corresponding author
}

\section{ARTICLE INFO}

\section{Article history}

Received August 21, 2017

Revised December 9, 2017

Accepted December 14, 2017

Keywords

DSS

Goat

AHP

Profile matching

TOPSIS

\section{ABSTRACT}

Goat farm businessman should considered environmental and financial criteria in breeding their commodities. The environmental factors are temperature, humidity, rain intensity, and altitude. For financial criteria, used several sub criteria i.e NPV (Net Present Value), ROI (Return On Investment), BCR (Benefit Cost Ratio), PBP (Payback Period), and BEP (Break Event Point) to determine financial feasibility. This research aims to develop a decision support system for selecting type of goat to breed by combining AHP, Profile Matching, and TOPSIS. AHP method was used for calculating the weight, Profile Matching for environment suitability evaluation, and TOPSIS for producing a valid decision that represents the goat expert's decision. The result showed that three methods can be integrated, and an experimental results which was validated by expert show that Bligon goat had the highest preference value $(0.8835847)$. This can be concluded that DSS decision was valid and it successfully represented expert's consideration.

This is an open access article under the CC-BY-SA license.

\section{Introduction}

Livestock breeding is an essential source support for urban and rural livelihood [1]. More than $90 \%$ farm business in Indonesian rural areas is small-scale farm with goats as its main commodity. Goats are easier to breed than big ruminants such as cows and buffalos, due to several aspects [2]. Viewed from the economic aspect, goat breeding is promising due to its small initial investment and low risk of loss. From the biological aspect, goats can eat various types of forage. From the aspect of farming implementation, goats can be easily raised well in a narrow area. These aspects make goats suitable for a family livestock business.

This study focused on an experimental integrated AHP, Profile Matching, and TOPSIS based on financial and environmental criteria for selecting various and unique goats such as Kacang, Peranakan Ettawa (PE), Bligon, and Saanen which raised in the region of Yogyakarta-Indonesia and the surrounding areas [3]. The breeders must select the goat with maximum environmental suitability and potential benefit. They must concern to the temperature [3,4], humidity [4], precipitation [3], and altitude [2]. Furthermore, the methods such as NPV (Net Present Value), ROI (Return on Investment), BCR (Benefit Cost Ratio), PBP (Payback Period), and BEP (Break Event Point) are used for financial analysis. Those important factors have the different criteria, where each criterion has the different importance 
level. This study employed a Decision Support System (DSS) to select the best goat based on those nine criteria.

Some definitions of DSS are stated in [5]. Researchers have developed DSS for selecting suitable or recommended location for business or strategic assets [6]-[10]. Some of them integrate or combine different method in DSS to achieve optimum performance for their cases [7]-[10].

This study concern to three DSS methods: AHP, Profile Matching, and TOPSIS. AHP is a combination of qualitative and quantitative methods for measuring the weight of the factors that influence certain case [5]. Gupta [11] applied AHP to select the best Hospital for surgery for heart disease patients. AHP was able to solve difficult and complex problems by breaking down the problem into smaller parts. AHP can be combined with another method. Rouyendegh et al. [12] implemented AHP and TOPSIS to rank the company sectors Turkey based on performance improvement after Enterprise Resource Planning (ERP) implementation. AHP was used for identifying the weight of each criterion and TOPSIS to rank alternatives. Ren et al. [13] conducted a health evaluation of wetland ecosystem using AHP-TOPSIS method. AHP used to determine the weight of each subsystem consisted of subsystems Pressure, State, and Response. The second approach, Profile Matching method was used to solve problem in a decision selection [14]. There were two parameters to be considered such as core and secondary factor. The use of Profile Matching could resolve the case of sorting dinamically and had accurate result. The third is TOPSIS, a method that could handle large-scale problems, identified the optimal target, and calculated the distance of each option with positive and negative ideal solution and sorted based on proximity to the ideal solution. Liu et al. [15] solved Supplier Manufacturing companies selection problem using TOPSIS. The benefit of this method was its simplicity and ability to produce an irrefragable preference order [16]. TOPSIS could be integrated with other methods to handle specific problems.

Considering the advantage of each previously explained method, this research proposes an integrated AHP, Profile Matching, and TOPSIS for selecting types of goat based on environment and financial criteria. AHP method is used for calculating the weight. Profile Matching is used for evaluating environment suitability. TOPSIS is implemented for producing a valid decision that represents the expert decision.

\section{Method}

This section explains the proposed integrated AHP, Profile Matching, and TOPSIS for selecting type of goats based on environment and financial criteria method. The proposed method is elaborated in the following subsections.

\subsection{Core Process in DSS}

There were four processes in goat selection process that would be implemented in Decision Support System. Those processes are illustrated in Fig. 1. Three of four processes such as Weight Calculation, Environment Suitability Evaluation, and Financial Analysis, have to be done before Alternative Ranking.

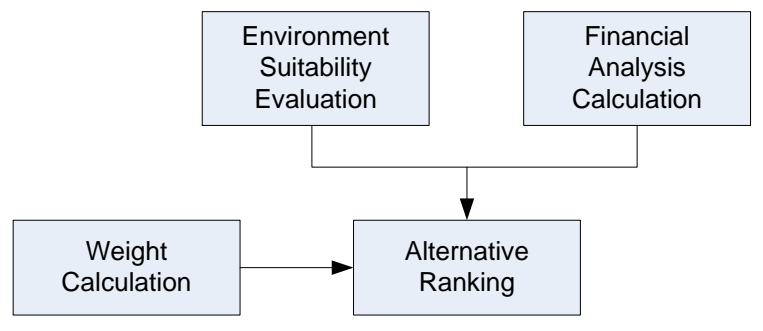

Fig. 1. Process in DSS

\subsection{Process Models in DSS}

Processes described on Fig. 1 are then broken down and showed in Fig. 2. 


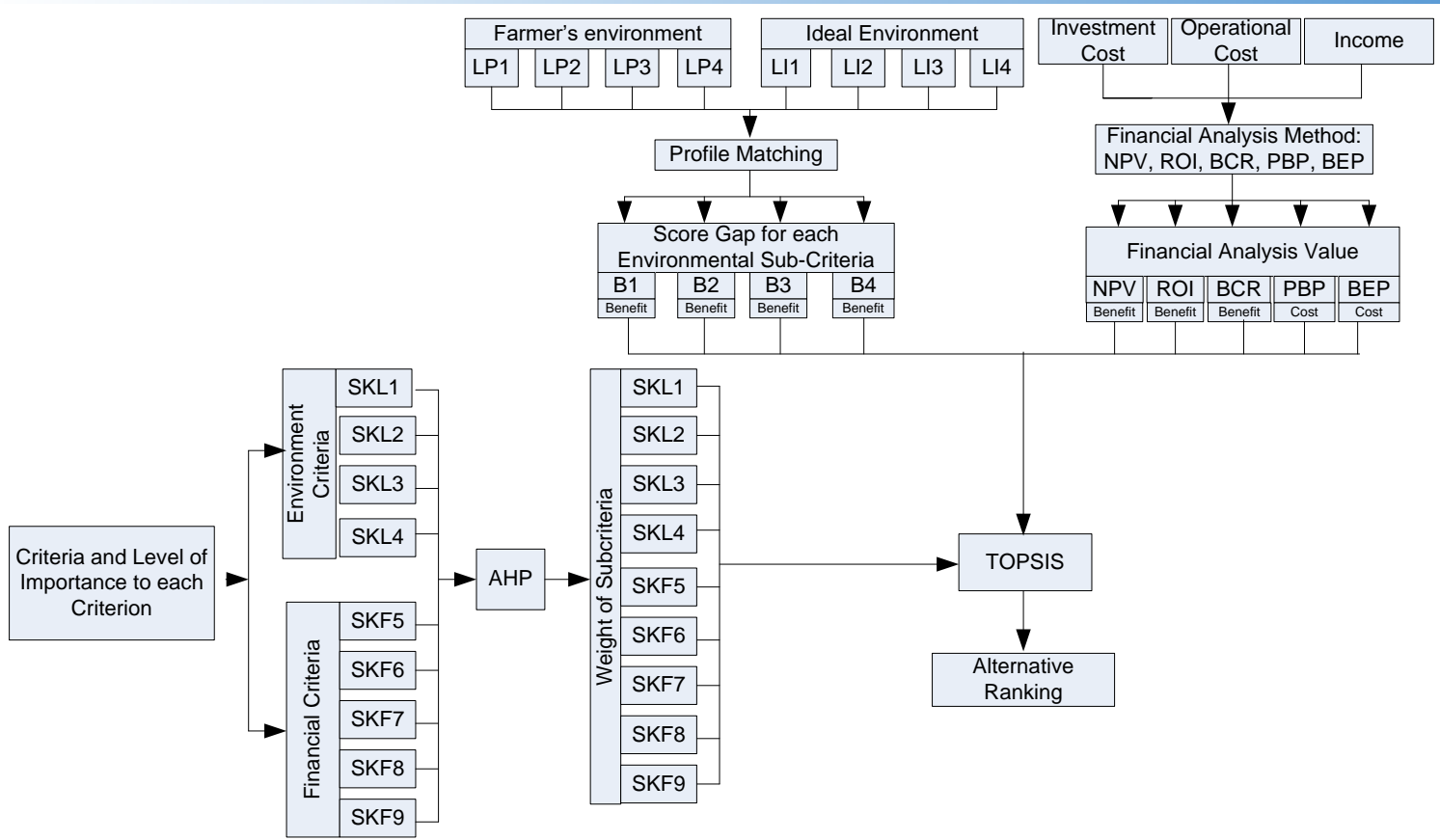

Fig. 2. Processes' model of DSS.

Referring to Fig. 2, the following is the description of the Processes' Model of DSS:

\section{1) Weight Calculation Model}

This model contained process to obtain weight of sub criteria. DSS received the input sub-criteria and their level of importance to each criterion. Environmental criteria consisted of sub-criteria: temperature (SKL1), humidity (SKL2), rainfall (SKL3), and the height of the area/altitude (KL4)). While the financial criteria consisted of: NPV (SKF5), ROI (SKF6), BCR (SKF7), PBP (SKF8) and BEP (SKF9)). The weight of sub-criteria would be calculated using AHP resulting sub-criteria weight such as the weight of temperature sub criteria (BS1), humidity (BS2), rainfall (BS3), altitude (BS4), NPV (BS5), ROI (BS6), BCR (BS7), PBP (BS8) and BEP (BS9). Here are the steps to decide the weight of sub-criteria [17]:

a) Establishing a pair wise matrix comparison $A$ as in (1) which its size $n \times n$, where $n$ is the number of criteria that will be compared. So, the size of matrix is $9 \times 9$. The Saaty's scale (1-9) is used to illustrate the importance of criteria compared with the other criteria in order to fill the matrix. Element $a_{i j}=1$ if $i=j$ and $a_{j i}=1 / a_{i j}$ if $i \neq j$.

$$
A=\left[\begin{array}{cccc}
1 & a_{12} & \Lambda & a \\
1 / a_{12} & 1 & \Lambda & a_{2 n} \\
\mathrm{M} & \mathrm{O} & \mathrm{O} & \mathrm{M} \\
1 / a_{1 n} & 1 / a_{2 n} & \Lambda & 1
\end{array}\right]
$$

b) Establishing a normalized matrix of $N$ as in (2).

$$
N=\left[\begin{array}{cccc}
1 & a_{12} & \Lambda & a_{1 n} \\
a_{21} & 1 & \Lambda & a_{2 n} \\
\mathrm{M} & \mathrm{O} & \mathrm{O} & \mathrm{M} \\
a_{n 1} & a_{n 2} & \Lambda & 1
\end{array}\right]_{\text {where }} a_{i j}=a_{i j} / \sum_{i=1}^{n} a_{i j}
$$

c) Calculating Priority Vector (VP) or Weight Vector $\left(W_{k}\right)$ by calculating the average of each row of the normalized matrix as shown in (3). 
$W_{k}=\frac{i}{n} \sum_{j=1}^{n} a_{i j}$

d) Calculating the maximum Eigen value of a matrix of the pair-wise comparisons $\left(\lambda_{\max }\right)$ by multiplying the sum of each column with the respective criteria of Vector Priority / Weight $\left(W_{k}\right)$ the result of the multiplication is then summed using (4).

$\lambda_{\max }=\sum_{k=1}^{n}\left[W_{k}\left(\sum_{i=1}^{n} a_{i j}\right)\right]$

e) Calculating the Consistency Index (CI) using (5) where $n$ is 9 .

$C I=\frac{\lambda_{\max }-n}{n-1}$

f) Calculating the Consistency Ratio (CR) using (6). RI or Random Index is obtained from Table 1 that is adjusted to the size of the matrix used.

$$
C R=\frac{C I}{R I}
$$

g) The Judgment Consistency can be checked by taking a CR from CI with a value that corresponds to Table 1 . The CR is accepted if the value does not exceed 0.10. Furthermore, the Judgment matrix is otherwise inconsistent. To obtain a consistent matrix, the judgment must be reviewed and corrected again.

Table 1. Random consistency

\begin{tabular}{cc}
\hline Size of Matrix & Random Consistency \\
\hline 1 & 0.00 \\
2 & 0.00 \\
3 & 0.58 \\
4 & 0.90 \\
5 & 1.12 \\
6 & 1.24 \\
7 & 1.32 \\
8 & 1.41 \\
9 & 1.45 \\
\hline
\end{tabular}

\section{2) Environment Variable Scoring Model}

This model contain evaluation process the suitability of farmer's environment compared to the ideal environmental condition. The DSS would accept environment variable input from the environmental conditions of the breeders who want to be evaluated, that consists of temperature condition (LP1), humidity condition (LP2), rainfall (LP3), and altitude (LP4) and input tolerance ideal environmental conditions. The input tolerance ideal environmental conditions given by experts for each type of the goat, which consisting of the ideal temperature tolerance (LI1), ideal humidity tolerance (LI2), ideal rainfall tolerance (LI3), and the ideal height area tolerance (LI4).

Condition of the environment variable input that would be evaluated matched the resemblance with the ideal environmental conditions using the Profile Matching method. Ideal environmental conditions from farming expert are shown in Table 2. Profile Matching process is calculated using (7). 


$$
y=\left\{\begin{array}{c}
\frac{x-x_{a}}{x_{1}-x_{a}}\left(y_{2}-y_{1}\right)+y_{1}, \text { if } x_{a} \leq x \leq x_{1} \\
y_{2}, \text { if } x_{1} \leq x \leq x_{2} \\
\frac{x-x_{2}}{x_{b}-x_{2}}\left(y_{1}-y_{2}\right)+y_{2}, \text { if } x_{2} \leq x \leq x_{b}
\end{array}\right.
$$

where $y$ is score gap to be found, $y_{1}$ for minimum score gap, $y_{2}$ represents maximum score gap, $x$ are alternative values, $x_{a}$ is minimum value, $x_{b}$ is maximum value, $x_{1}$ for minimum ideal environment value, and $x_{2}$ describes maximum ideal environment value.

Table 2. Ideal environmental condition for each type of goat

\begin{tabular}{lcccc}
\hline \multirow{2}{*}{ Alternative } & \multicolumn{4}{c}{ Environment Variable } \\
\cline { 2 - 5 } & Temperature $\left({ }^{\boldsymbol{}} \boldsymbol{C}\right)$ & Humidity $(\boldsymbol{\%})$ & Rainfall $(\boldsymbol{m m} / \boldsymbol{y r})$ & Altitude (masl) \\
\hline Kacang & $30-35$ & $68-88$ & $2012-2736$ & $100-300$ \\
PE & $20-28$ & $61-85$ & $2318-3629$ & $612-950$ \\
Bligon & $23-32$ & $80-85$ & $1920-2240$ & $100-300$ \\
Saanen & $20-28$ & $61-85$ & $2142-3684$ & $600-770$ \\
\hline
\end{tabular}

The result of the calculation from the Profile Matching would produce the weight/score gap for each environmental sub criteria, such as: Weight/Score Gap temperature (B1), Weight/Score Gap humidity (B2), Weight/Score Gap precipitation (B3), and Weight/Score Gap altitude (B4).

\section{3) The Financial Analysis Model}

The DSS would accept input such as investment cost, operational cost, and income from of each type of the goat. The input would be analyzed using financial analysis formula like NPV, ROI, BCR, PBP, and $\mathrm{BEP}$ and resulting NPV, ROI, BCR, PBP, and BEP values of each type of the goat. Here is the explanation of each financial method:

a) Net Present Value (NPV)

According to Žižlavský [18], Net Present Value is obtained by discounting all future cash in and cash out flows from a project with a given discount rate and then summing them together. This method uses the consideration that the present value of money is higher compared with the future value of money. $\mathrm{NPV}$ is calculated using (8) where $B_{t}$ is the benefit within year- $t, C_{t}$ is the cost within year- $t, n$ is the age of project, $t$ is the year, and $i$ is the discount rate.

$$
N P V=\sum_{t=0}^{n} \frac{\left(B_{t}-C_{t}\right)}{(1+i)^{t}}
$$

b) Return On Investment (ROI)

ROI indicates the profitability of an investment. As mentioned in [19], ROI is the ratio of annual financial resource gained or lost to the investment. ROI is calculated using (9) where $I$ is the investment.

$$
R O I=\frac{N P V-I}{I}
$$

\section{c) Benefit Cost Ratio (BCR)}

$\mathrm{BCR}$ is a comparison between the present value of the result and the cost of capital. BCR is used as an indication of whether investment can be applied or not. BCR analysis aims to determine the amount of benefits of an investment. BCR is calculated using (10). 


$$
B C R=\frac{\sum_{i=0}^{n} \frac{\left(B_{t}\right)}{(1+i)^{t}}}{\sum_{i=0}^{n} \frac{\left(C_{t}\right)}{(1+i)^{t}}}
$$

d) Payback Period (PBP)

Payback Period is the time required to return the investment value through revenue generated by the investment project. PBP is calculated using (11).

$$
P B P=\frac{I}{B(1+i)^{i}}
$$

e) Break Even Point (BEP)

Break Even analysis is used to estimate how minimum a company should be able to produce and sell its products in order not to suffer loss. Break Even Point is the point where profit is equal to cost [20]. $B E P$ is calculated using (12) where $T C$ is the total cost and $b P$ is the price per goat. An investment is said to be profitable if value of NPV, ROI, and BCR are tend to be high and BEP and PBP are tend to be low.

$$
B E P \quad \text { (amount of production) }=\frac{T C}{h P}
$$

\section{4) The Alternative Ranking Model}

The results from the weight/score-gap calculation and the value of financial analysis of each alternative would be processed using TOPSIS to obtain the ranking of each alternative. TOPSIS reflects the issues about picking decisions to be represented in the form of a decision matrix with $m$ rows that represents an alternative, and $n$ columns that represents the evaluation criteria. The matrix consists of variable $X_{j k}$ which each variable describes of performance from alternative $A_{j}(j=1, \ldots, m)$ that is associated with the criteria of $C_{k}(k=1, \ldots, n)$. In addition, decision makers define the weight vector as $w=\left(w_{1}\right.$, $\left.w_{2}, \ldots, w_{n}\right)$, the weight reflects the relative importance of each criterion. The normal TOPSIS consists of six steps as follows [21]:

a) Building a Normalized Decision Matrix as in (13) where $\hat{x}_{j k}$ is the matrix elements for $j=1, \ldots$, $m$ and $k=1, \ldots, n$.

$$
N=\left[\begin{array}{cccc}
\dot{x}_{11} & \dot{x}_{12} & \Lambda & \dot{x}_{1 n} \\
\dot{x}_{21} & \dot{x}_{22} & \Lambda & \dot{x}_{2 n} \\
\mathrm{M} & 0 & 0 & \mathrm{M} \\
\dot{x}_{m 1} & \hat{x}_{m 2} & \Lambda & \dot{x}_{m n}
\end{array}\right] \text { where } \dot{x}_{j k}=\frac{x_{j k}}{\sqrt{\sum_{j=1}^{m} x_{j k}^{2}}}
$$

b) Calculating the normalized Weight Decision Matrix using (14). The weights in this calculation are derived from the AHP calculation in point 1 .

$$
V=\left[\begin{array}{cccc}
w_{1} \dot{x}_{11} & w_{2} \hat{x}_{12} & \Lambda & w_{n} \dot{x}_{1 n} \\
w_{1} \dot{x}_{21} & w_{2} \hat{x}_{22} & \Lambda & w_{n} \dot{x}_{2 n} \\
\mathrm{M} & \mathrm{O} & \mathrm{O} & \mathrm{M} \\
w_{1} \hat{x}_{m 1} & w_{2} \hat{x}_{m 2} & \Lambda & w_{n} \dot{x}_{m n}
\end{array}\right]=\left[\begin{array}{cccc}
v_{11} & v_{12} & \Lambda & v_{1 n} \\
v_{21} & v_{22} & \Lambda & v_{2 n} \\
\mathrm{M} & \mathrm{O} & \mathrm{O} & \mathrm{M} \\
v_{m 1} & v_{m 2} & \Lambda & v_{m n}
\end{array}\right]
$$


c) Determining the Positive Ideal Solution $\left(\mathrm{A}^{+}\right)$as in $(15)$ and the Negative Ideal Solution $\left(\mathrm{A}^{-}\right)$as in (16).

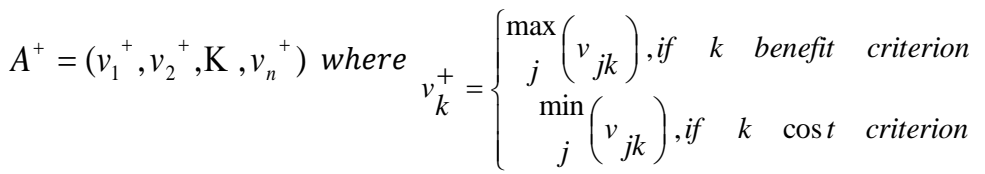

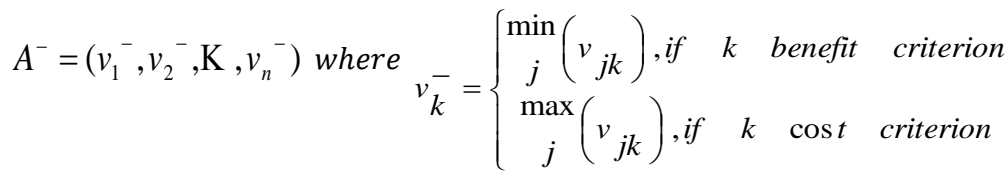

d) Calculating the distance from the value of any positive ideal solution $\left(d_{j}^{+}\right)$and negative ideal solution $\left(d_{j}\right)$ to each alternative using (17) and (18) respectively.

$$
\begin{aligned}
& d_{j}^{+}=\sqrt[p]{\sum_{k=1}^{n}\left|v_{j k}-v_{k}^{+}\right|^{p}}, \text { for } j=1, \mathrm{~K}, m \\
& d_{j}^{-}=\sqrt[p]{\sum_{k=1}^{n}\left|v_{j k}-v_{k}^{-}\right|^{p}}, \text { for } j=1, \mathrm{~K}, m
\end{aligned}
$$

e) Determining the relative proximity of each alternative to the ideal solution using (19).

$$
s_{j}=\frac{d_{j}^{-}}{d_{j}^{+}-d_{j}^{-}}, \text {for } \quad j=1, \mathrm{~K}, m
$$

Descending the order of the rank alternatives by using $S_{j}$ to obtain the most appropriate alternatives decision.

\section{Results and Discussion}

DSS would perform four processes that have been illustrated in Fig. 1.

\subsection{The Weight Calculation}

The variable of sub-criteria level and importance information that were obtained from the experts as shown in Table 3 were processed using AHP method to produce weight for each sub-criterion.

Table 3. Comparison Value for Environment Variable

\begin{tabular}{ccc}
\hline Sub-criteria Variable & Comparison Value & Sub-criteria Variable \\
\hline Temperature & 2 & Humidity \\
Temperature & 4 & Rainfall \\
Temperature & 6 & Altitude \\
Humidity & 3 & Rainfall \\
Humidity & 5 & Altitude \\
Rainfall & 4 & Altitude \\
\hline
\end{tabular}

Comparison value would be constructed into a pairwise comparison matrix like shown in (1). 


$$
N=\left[\begin{array}{llll}
1.0000 & 2.0000 & 4.0000 & 6.0000 \\
0.5000 & 1.0000 & 3.0000 & 5.0000 \\
0.2500 & 0.3333 & 1.0000 & 4.0000 \\
0.1667 & 0.2000 & 0.2500 & 1.0000
\end{array}\right]
$$

Each element from pairwise comparison matrix is normalized using (2) to establish Normalized Matrix $N$.

$$
N=\left[\begin{array}{llll}
0.521730 & 0.56657 & 0.484848 & 0.37500 \\
0.260865 & 0.28328 & 0.363636 & 0.31250 \\
0.130433 & 0.09348 & 0.121212 & 4.00000 \\
0.086970 & 0.05666 & 0.030303 & 0.06250
\end{array}\right]
$$

Next, the Priority Vector (VP) is generated using (3).

$$
V P=\left[\begin{array}{l}
0.48690634 \\
0.30500620 \\
0.14899663 \\
0.05909083
\end{array}\right]
$$

After obtaining Priority Vector, the calculation is performed using (4) until (6) to check whether the comparison matrix is consistent or not. This calculation produced CR value below 0.1 indicating that matrix is consistent. Each element from Priority Vector then multiplied with corresponding global weight of each criterion to obtain weight of each sub-criterion as shown in Table 4. Global weight for environment criteria is 0.75 and 0.25 for financial criteria. These global weights are determined by Expert Judgment.

Table 4. Result of Weight Calculation

\begin{tabular}{ccc}
\hline Criteria & Variable & Value \\
\hline & Temperature & 0.36517975 \\
The Environment & Humidity & 0.22875464 \\
Variable & Rain Intensity & 0.11174747 \\
& Altitude & 0.04431812 \\
& NPV & 0.10878757 \\
\hline \multirow{2}{*}{ Financial Analysis } & ROI & 0.07206277 \\
& BCR & 0.04005351 \\
& PBP & 0.02063266 \\
& BEP & 0.00846346 \\
\hline
\end{tabular}

\subsection{The Evaluation of Environmental Suitability}

Table 5 shows the environmental conditions that will be evaluated with the ideal environmental conditions in the Table 1 using (7). The result of the calculation to obtain the weight/score-gap or the value of environmental suitability is shown in the Table 6.

Table 5. The Input of Breeders' environmental condition

\begin{tabular}{ccccc} 
& Temperature & Humidity & Rainfall & Altitude \\
\hline User Input & $26^{\circ} \mathrm{C}$ & $80 \%$ & $3100 \mathrm{~mm} /$ year & Mdpl \\
\hline
\end{tabular}

Table 6. The scores of environmental suitability

\begin{tabular}{ccccc}
\hline \multirow{2}{*}{ Alternative } & \multicolumn{4}{c}{ Score Gap (The Environment Suitability) } \\
\cline { 2 - 5 } & Temperature & Humidity & Rain Intensity & Altitude \\
\hline Kacang & 2.4 & 4 & 3.516921 & 3.058824 \\
PE & 4.0 & 4 & 4.000000 & 4.000000 \\
Bligon & 4.0 & 4 & 3.019943 & 3.058824 \\
Saanen & 4.0 & 4 & 4.000000 & 4.000000 \\
\hline
\end{tabular}




\subsection{The Calculation of Financial Analysis}

The financial data of each goat from the Cash Flow as shown in Table 7 are calculated using (8) (12) to produce results as shown in Table 8.

Table 7. Cash flow example for Bligon goat

\begin{tabular}{|c|c|c|c|c|c|c|}
\hline Description & Year 0 & Year 1 & Year 2 & Year 3 & Year 4 & Year 5 \\
\hline \multicolumn{7}{|l|}{ CASH IN FLOW (IDR) } \\
\hline 1. Sale value of goat & - & $5,400,000$ & $5,400,000$ & $5,400,000$ & $5,400,000$ & $5,400,000$ \\
\hline 2. Sale value of goat droppings & - & 60,000 & 60,000 & 60,000 & 60,000 & 60,000 \\
\hline 3. Sale value of milk & - & $2,700,000$ & $2,700,000$ & $2,700,000$ & $2,700,000$ & $2,700,000$ \\
\hline TOTAL CASH IN FLOW & - & $8,160,000$ & $8,160,000$ & $8,160,000$ & $8,160,000$ & $8,160,000$ \\
\hline \multicolumn{7}{|l|}{ CASH OUT FLOW (IDR) } \\
\hline \multicolumn{7}{|l|}{ Fix Investment } \\
\hline 1. Cost of making cage & 800,000 & - & - & - & - & - \\
\hline 2. Cost of purchasing tools & 125,000 & - & - & - & - & - \\
\hline 3. Cost of purchasing goats & $4,500,000$ & - & - & - & - & - \\
\hline Total Investment Cost & $5,425,000$ & - & - & - & - & - \\
\hline \multicolumn{7}{|l|}{ Operational Cost } \\
\hline 1. Cost of health & - & 400,000 & 400,000 & 400,000 & 400,000 & 400,000 \\
\hline 2. Cost of concentrate & - & $2,628,000$ & $2,628,000$ & $2,628,000$ & $2,628,000$ & $2,628,000$ \\
\hline Total Operational Cost & - & $3,028,000$ & $3,028,000$ & $3,028,000$ & $3,028,000$ & $3,028,000$ \\
\hline TOTAL CASH OUT FLOW & $5,425,000$ & $3,028,000$ & $3,028,000$ & $3,028,000$ & $3,028,000$ & $3,028,000$ \\
\hline NET CASH FLOW & $(5,425,000)$ & $5,132,000$ & $5,132,000$ & $5,132,000$ & $5,132,000$ & $5,132,000$ \\
\hline CUMMULATIVE & $(5,425,000)$ & $(293,000)$ & $4,839,000$ & $9,971,000$ & $15,103,000$ & $20,235,000$ \\
\hline
\end{tabular}

Table 8. The result of financial analysis

\begin{tabular}{cccccc}
\hline \multirow{2}{*}{ Alternative } & \multicolumn{5}{c}{ Financial Analvsis Value } \\
\cline { 2 - 6 } & $\boldsymbol{N P V}$ & $\boldsymbol{R O I}$ & $\boldsymbol{B C R}$ & $\boldsymbol{P B P}$ & $\boldsymbol{B E P}$ \\
\hline Kacang & $198,493.56$ & $(0.95)$ & 1.022565 & 0.037872 & 4.40 \\
$P E$ & $3,309,621.90$ & $(0.64)$ & 1.193598 & 0.037631 & 5.70 \\
Bligon & $5,381,855.14$ & $(0.01)$ & 1.456039 & 0.026567 & 6.56 \\
Saanen & $3,899,621.90$ & $(0.55)$ & 1.234983 & 0.035503 & 5.53 \\
\hline
\end{tabular}

\subsection{The Alternative Ranking}

The environmental suitability value in Table 6 and the results of the calculation of financial analysis in Table 8 as well as the weight of sub-criteria in Table 4 would be calculated using TOPSIS method in order to decide the type of the appropriate goats for breeding, regarding to the environmental conditions and the values of financial analysis. The results from the weight/score-gap calculation and the value of financial analysis of each alternative are combined into decision matrix $A$ as follows.

$$
A=\left[\begin{array}{rrrrrrrrr}
2.4 & 4.0 & 3.516921 & 3.05882 & 198,493.56 & -0.95 & 1.0225 & 0.0378 & 4.40 \\
4.0 & 4.0 & 4.000000 & 4.00000 & 3,309,621.90 & -0.64 & 1.1935 & 0.0376 & 5.70 \\
4.0 & 4.0 & 3.019940 & 3.05882 & 5,381,855.14 & -0.01 & 1.4560 & 0.0260 & 6.56 \\
4.0 & 4.0 & 4.000000 & 4.00000 & 3,899,621.90 & -0.55 & 1.2349 & 0.0350 & 5.53
\end{array}\right]
$$

The decision matrix is normalized using (13) as shown in matrix $N$ as follows.

$$
N=\left[\begin{array}{lllllllll}
0.32732684 & 0.5 & 0.48087 & 0.4295 & 0.0267 & -0.7500 & 0.41349 & 0.54568 & 0.39270 \\
0.54554473 & 0.5 & 0.54692 & 0.5616 & 0.4456 & -0.5015 & 0.48265 & 0.54221 & 0.50880 \\
0.54554473 & 0.5 & 0.41292 & 0.4295 & 0.7246 & -0.0062 & 0.58878 & 0.38280 & 0.58546 \\
0.54554473 & 0.5 & 0.54692 & 0.5616 & 0.5250 & -0.4311 & 0.49939 & 0.51155 & 0.49000
\end{array}\right]
$$


The next step is to calculate normalized weight decision matrix $W$ using (14).

$$
W=\left[\begin{array}{lllllllll}
0.11953 & 0.11437 & 0.053730 & 0.01903 & 0.00290 & -0.05404 & 0.01656 & 0.011250 & 0.00330 \\
0.19922 & 0.11437 & 0.061110 & 0.02489 & 0.04847 & -0.03614 & 0.01933 & 0.011187 & 0.00430 \\
0.19922 & 0.11437 & 0.046140 & 0.01903 & 0.07882 & -0.00045 & 0.02358 & 0.007890 & 0.00490 \\
0.19922 & 0.11437 & 0.061117 & 0.02489 & 0.05711 & -0.03107 & 0.02000 & 0.010550 & 0.00418
\end{array}\right]
$$

Then using (15) and (16) the Positive Ideal Solution and Negative Ideal Solution are determined as shown in Table 9.

Table 9. Positive ideal solution $\left(\mathrm{A}^{+}\right)$and negative ideal solution $\left(\mathrm{A}^{-}\right)$

\begin{tabular}{ccc}
\hline Sub-Criteria & $\mathbf{A}^{+}$ & $\mathbf{A}^{-}$ \\
\hline Temperature & 0.199221890 & 0.119533130 \\
Humidity & 0.114377325 & 0.114377325 \\
Rainfall & 0.061117604 & 0.046142920 \\
Humidity & 0.024893304 & 0.019036056 \\
NPV & 0.078828237 & 0.002907343 \\
ROI & -0.000450000 & -0.054050000 \\
BCR & 0.023582839 & 0.016562038 \\
PBP & 0.007898206 & 0.011259000 \\
BEP & 0.003324000 & 0.004955000
\end{tabular}

The next calculation is determining Alternatives' distance to Positive and Negative Ideal Solution using (17) and (18). the results are shown in Table 10. The last step is, determining Alternatives' Relative Closeness Value to Ideal Solution using (19) and the results are shown in Table 11. The value is then ranked using descending order to obtain the largest value as the most appropriate alternative decision. From Table 11, after the ranked is done, the most appropriate type of goat is Bligon that has the largest value.

Table 10. Alternatives' distance to positive and negative ideal solution

\begin{tabular}{cccc}
\hline & Distance to $A^{+}$ & \multicolumn{2}{c}{ Distance to $A^{-}$} \\
\hline $\mathrm{d}_{1}{ }^{+}$ & 0.123029490 & $\mathrm{~d}_{1}{ }^{-}$ & 0.007766697 \\
$\mathrm{~d}_{2}{ }^{+}$ & 0.047169854 & $\mathrm{~d}_{2}{ }^{-}$ & 0.094942356 \\
$\mathrm{~d}_{3}{ }^{+}$ & 0.016161944 & $\mathrm{~d}_{3}{ }^{-}$ & 0.122668116 \\
$\mathrm{~d}_{4}{ }^{+}$ & 0.037808996 & $\mathrm{~d}_{4}{ }^{-}$ & 0.100441523
\end{tabular}

Table 11. Alternatives' relative closeness value to ideal solution

\begin{tabular}{lc}
\hline \multicolumn{3}{c}{ Alternatives' Relative Closeness Value to Ideal Solution } \\
\hline $\mathrm{S}_{1 \text { (kacang) }}$ & 0.059380150 \\
$\mathrm{~S}_{2 \text { (PE) }}$ & 0.668080218 \\
$\mathrm{~S}_{3 \text { (Bligon) }}$ & 0.883584691 \\
$\mathrm{~S}_{4}$ (Saanen) & 0.726518232 \\
\hline
\end{tabular}

Decision testing of the DSS was done by comparing the decision of DSS with the decision of animal experts. There are several test cases to be evaluated. The conclusion can be seen at Table 12 . Number 1 shows the testing result of breeder's environment condition as stated in Table 4. Number 2 until 8 show testing result from another environment condition input. The result shows that the decision of DSS was valid and it was same with the expert's decision. 
Table 12. Testing result

\begin{tabular}{|c|c|c|c|c|c|c|c|}
\hline \multirow[b]{2}{*}{ No } & \multicolumn{4}{|c|}{ Test Case } & \multicolumn{2}{|c|}{ Decision Result } & \multirow[b]{2}{*}{ Conclusion } \\
\hline & $\begin{array}{c}\text { Temperature } \\
(C)\end{array}$ & $\begin{array}{l}\text { Humidity } \\
\text { (\%) }\end{array}$ & $\begin{array}{l}\text { Rain Intensity } \\
(\mathrm{mm} / \mathrm{yr})\end{array}$ & $\begin{array}{c}\text { Altitude } \\
\text { (masl) }\end{array}$ & $\begin{array}{c}\text { Expert } \\
\text { Decision }\end{array}$ & DSS Decision & \\
\hline 1 & 26 & 80 & 3100 & 700 & Bligon & Bligon & Valid \\
\hline 2 & 30 & 68 & 2182 & 112 & Bligon & Bligon & Valid \\
\hline 3 & 22 & 80 & 2400 & 950 & $P E$ & $P E$ & Valid \\
\hline 4 & 32 & 80 & 1955 & 100 & Bligon & Bligon & Valid \\
\hline 5 & 23 & 64 & 2345 & 1287 & $\widehat{P E}$ & $\widehat{P E}$ & Valid \\
\hline 6 & 31 & 67 & 2584 & 100 & Bligon & Bligon & Valid \\
\hline 7 & 22 & 83 & 4488 & 900 & $\widehat{P E}$ & $P E$ & Valid \\
\hline 8 & 26 & 88 & 451 & 40 & Bligon & Bligon & Valid \\
\hline
\end{tabular}

\section{Conclusion}

The developed DSS integrates AHP method for calculating the weight, Profile Matching for evaluation, and TOPSIS, represents the expert's decision in determining the type of the goat to be bred in a husbandry. For future research, ANP could be used for weighting. This approach concerns to the dependency between criteria and sub-criteria.

\section{Acknowledgment}

This research was supported by Lembaga Pengelola Dana Pendidikan (LPDP) of the Republic of Indonesia based on Decree No. KEP-19/LPDP/2016, and Balai Pembibitan dan Budidaya Ternak Ruminansia, Kaligesing, Purworejo - Indonesia.

\section{References}

[1] D. W. J. Foeken and S. O. Owuor, "Farming as a livelihood source for the urban poor of Nakuru, Kenya," Geoforum, vol. 39, no. 6, pp. 1978-1990, Nov. 2008, doi: https://doi.org/10.1016/j.geoforum.2008.07.011.

[2] C. Devendra and G. B. McLeroy, Goat and sheep production in the tropics. Longman Group, 1982, available at: https://www.cabdirect.org/cabdirect/abstract/19830174628.

[3] T. A. Kusumastuti and B. Susilo. Perkammunoan ternak kambino. wahana eduwisata dan sentra troduksi di nedesaan (tendekatan ekonomi lingkungan berbsis sistem ekonomi geografis). Yogyakarta: Gadjah Mada University Press, 2014.

[4] M. Wodzicka-Tomaszewska and M. Mastika, Produksi kambing dan domba di Indonesia. Sebelas Maret University Press, 1993.

[5] E. Turban, J. E. Aronson, and T.-P. Liang, Decision support systems and intelligent systems. Pearson/Prentice Hall, 2005.

[6] F. Dweiri, S. Kumar, S. A. Khan, and V. Jain, "Designing an integrated AHP based decision support system for supplier selection in automotive industry," Expert Syst. Appl., vol. 62, pp. 273-283, Nov. 2016, doi: https://doi.org/10.1016/j.eswa.2016.06.030.

[7] C. López and A. Ishizaka, "A hybrid FCM-AHP approach to predict impacts of offshore outsourcing location decisions on supply chain resilience," J. Bus. Res., Oct. 2017, doi: https://doi.org/10.1016/j.jbusres.2017.09.050.

[8] B. Sennaroglu and G. Varlik Celebi, "A military airport location selection by AHP integrated PROMETHEE and VIKOR methods," Transp. Res. Part D Transp. Environ., vol. 59, pp. 160-173, Mar. 2018, doi: https://doi.org/10.1016/j.trd.2017.12.022.

[9] N. Yildız and F. Tüysüz, "A hybrid multi-criteria decision making approach for strategic retail location investment: Application to Turkish food retailing," Socioecon. Plann. Sci., Mar. 2018, doi: https://doi.org/10.1016/j.seps.2018.02.006.

[10] C. Franco, M. Bojesen, J. L. Hougaard, and K. Nielsen, "A fuzzy approach to a multiple criteria and Geographical Information System for decision support on suitable locations for biogas plants," Appl. Energy, vol. 140, pp. 304-315, Feb. 2015, doi: https://doi.org/10.1016/j.apenergy.2014.11.060. 
[11] H. Gupta, "Selection of best hospital for surgery using AHP", IUP Journal Of Operations Management, vol. 14, no. 3, pp. 18-32, 2015, available at: https://goo.gl/zGEWn7.

[12] B. D. Rouyendegh, U. Baç, and T. E. Erkan, "Sector selection for ERP implementation to achieve most impact on supply chain performance by using AHP TOPSIS hybrid method," Tehnicki Vjesnik/Technical Gazette, vol. 21, no. 5, pp. 933-937, 2014, available at: https://goo.gl/AnbTgk.

[13] L. Ren, J.-T. Liu, J.-J. Ni, and X.-Y. Xiang, "Health evaluation of a lake wetland ecosystem based on the TOPSIS method," Polish J. Environ. Stud., vol. 23, no. 6, pp. 2183-2190, 2014, available at: http://www.pjoes.com/pdf/23.6/Pol.J.Environ.Stud.Vol.23.No.6.2183-2190.pdf.

[14] Z. Tharo and A. P. U. Siahaan, "Profile Matching in Solving Rank Problem," IOSR J. Electron. Commun. Eng., vol. 11, no. 5, pp. 73-76, 2016, doi: https://doi.org/10.9790/2834-1105017376.

[15] Y. Liu, P. L. Zhang, and H. G. Liu, "Manufacturing Enterprise Suppliers Selection Based on Improved TOPSIS Method," Appl. Mech. Mater., vol. 602-605, pp. 41-44, Aug. 2014, doi: https://doi.org/10.4028/www.scientific.net/AMM.602-605.41.

[16] E. Eraslan and Y. Tansel İç, "A multi-criteria approach for determination of investment regions: Turkish case," Ind. Manag. Data Syst., vol. 111, no. 6, pp. 890-909, Jun. 2011, doi: https://doi.org/10.1108/02635571111144964.

[17] Y. Zhang and L. Feng, "Evaluation and optimization of children's recreational center in urban green public space based on AHP-TOPSIS," J. Appl. Sci., vol. 13, no. 6, pp. 895-900, Jun. 2013, doi: https://doi.org/10.3923/jas.2013.895.900.

[18] O. Žižlavský, "Net present value approach: method for economic assessment of innovation projects," Procedia - Soc. Behav. Sci., vol. 156, pp. 506-512, Nov. 2014, doi: https://doi.org/10.1016/j.sbspro.2014.11.230.

[19] E. Wahab, A. Shamsuddin, N. H. Abdullah, and N. A. Hamid, "Users' satisfaction and return on investment (ROI) for online database library databases: a malaysian technical university perspective," Procedia - Soc. Behav. Sci., vol. 219, pp. 777-783, May 2016, doi: https://doi.org/10.1016/j.sbspro.2016.05.075.

[20] D. Ofileanu and S. S. Bumbescu, "The analysis of the factors which influence the change of the breakeven point," Procedia Econ. Financ., vol. 16, pp. 356-367, Jan. 2014, doi: https://doi.org/10.1016/S22125671(14)00814-4.

[21] T. Wachowicz and P. Błaszczyk, "TOPSIS based approach to scoring negotiating offers in negotiation support systems," Gr. Decis. Negot., vol. 22, no. 6, pp. 1021-1050, Nov. 2013, doi: https://doi.org/10.1007/s10726012-9299-1. 